\title{
CUSTOMS' ROLE IN OVERCOMING COVID-19 OUTBREAK: THE CASE OF INDONESIA
}

\author{
Diyouva Christa Novith \\ Muhammad Hadiyan Ridho
}

1.2 Department of Accounting, Polytechnic of State Finance STAN, Indonesia

Email:diyouva@gmail.com and mhadiyanridhooo@gmail.com

\author{
ARTICLE INFORMATION \\ Received date \\ [30-09-2020] \\ Revision \\ [01-12-2020] \\ Accepted date \\ [22-12-2020]
}

\begin{abstract}
:
The global pandemic so-called COVID-19 disrupts supply chain and have an impact on numerous sectors. The adversity suffered by most of the countries is severe shortage of medical supply input. In addition, the nuisance on supply chain also affects economic growth and the most affected are firms which operations are related to international trade. Customs as related institution in international trade has a vital role in sustaining the supply chain continuity. This paper is quantitative research with descriptive statistics method. The paper analyses the policies implemented by customs authority and provide the data analysis in statistical form with descriptive narrative. Our findings depict how the preliminary steps that taken affect domestic supply by stimulating cross-border trade. Our result also show that fiscal incentives successfully escalate medical equipment supply via importation and take a role on national balance trade, but procedural support provided can't handle numerous of importation of medical supplies so there's no changes in dwelling time. The outcomes and findings of our study can be used by government or researchers as an evaluation for progressing the further support systems guiding supply chain.
\end{abstract}

Keywords: Customs, COVID-19, International Trade, Supply Chain. 


\section{INTRODUCTION}

World Health Organization (WHO) on 31 December 2019 declared COVID-19 as become a global health problem. The coronavirus outbreak is predicted to deliver the biggest contraction in global economy since the Great Depression. According the report from World Health Organization (WHO) on the 20th of April 2020, there were 2.3 million confirmed cases globally and the number continues to increase gradually (World Health Organization, 2020). In Indonesia the COVID-19 outbreak that started since 2020 is perceived as one of the most difficult outlooks in Asia. Starting the first case of COVID19 announced on the 3rd of March until July 22, 2020 at 12.00 p.m. Indonesia already reported 91.751 positive cases, 4.459 death, 50.255 recovered spread in 34 provinces, 469 cities (Ministry of Health of the Republic Indonesia) and became the $22^{\text {nd }}$ place of number of confirmed Covid-19 according to WHO publication.

Figure 1. COVID-19 Case in Indonesia

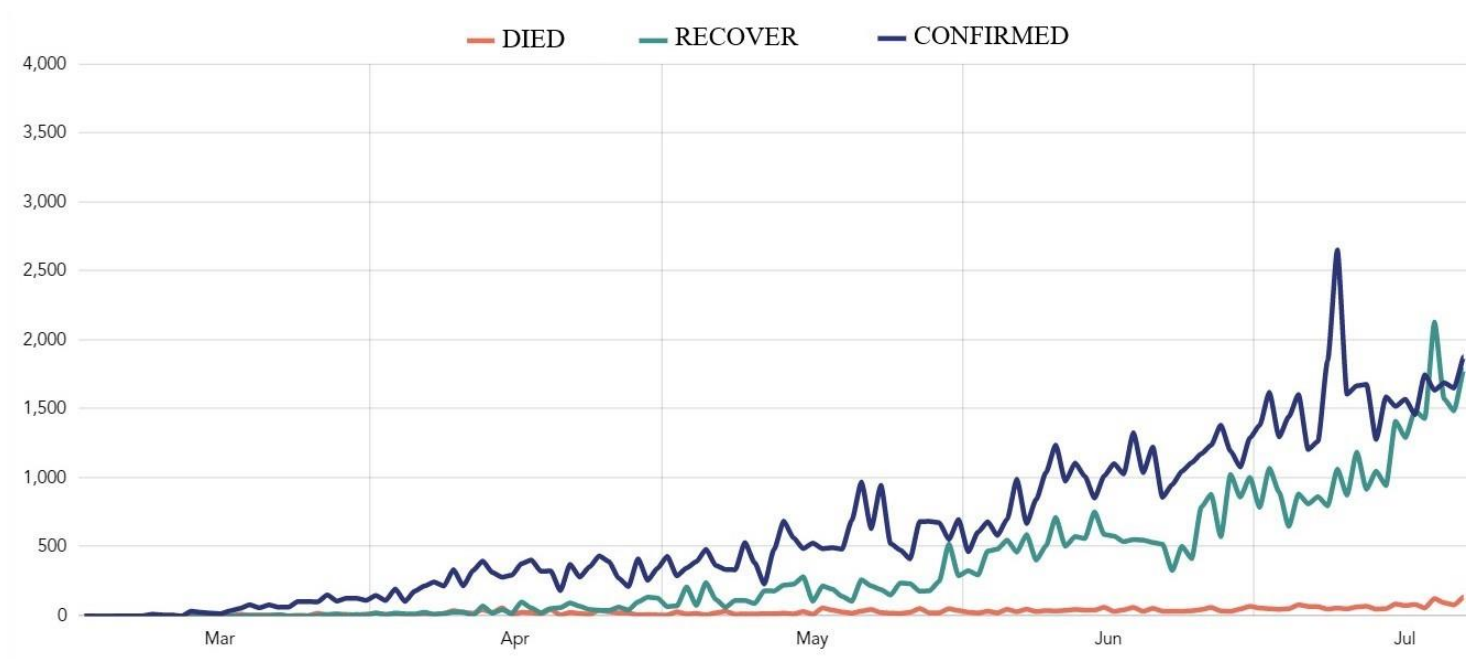

Source: https://covid19.go.id/peta-sebaran

The pandemic has incurred severe damage on social, health, economic and financial aspect. The domino effect has been able to be identified primarily on Indonesia's healthcare system and the policies that have been implemented. Large-scale social distancing, school closures, work from home and other public policies have been taken by Indonesia due to flattening the curve and also affect national economic movements. Declining economic movement reflects on the downfall of consumption aggregate, investment deterioration, the setback of cross-border trades and the sagging of economic growth rate. In the first quarter of 2020 gross domestic product of Indonesia fell down to 
$2.97 \%$ and for the first time since 1999 Indonesia's economy shrinks to $-5.32 \%$ in the second quarter. The government's dependency on foreign capital inflows has made it worst. The mass exodus of foreign capital from Indonesian capital markets because of COVID-19 makes the financial sector volatility and turmoil as investors steered away and the rupiah (Indonesia currency) exchange rate had depreciated by 11.3 percent within less than a month after the announcement of the COVID-19 pandemic.

The derailing economic gives Indonesia short of choice supporting healthcare system. As news came with reports of inadequate medical facilities and personnel, Indonesian Ombudsman said that the hospitals are also lack of preparation to counter the coronavirus pandemic. Lack of medicine and medical devices are crucial thing in order to suppress the COVID-19 case and owing to short supply of protective gear, the deaths of medical personnel as patient number continue to surge. The frustration of medical workers is as medical supplies become depleted. Moreover, panic buying has hit markets. The shift in Indonesia consumers' behavior increased demand for both staple foods and certain items such as masks and hand sanitizer. On the other hand, supply chains are being broken by the prevention efforts such as social distancing and travel restrictions. This pandemic cause major disruptions not only in Indonesia but also global supply chain systems. According to the World Trade Organization, cross border trades could fall $13 \%$ to $32 \%$ in 2020 depending on the scenario modeled.

Putting a strain on the economy both in terms of supply and demand leaves government no choice but to takes coordinated preliminary steps to undergo COVID-19. As stated in PERPPU No. 1 Tahun 2020 State Financial Policies and Financial System Stability for Handling Pandemic Corona Virus Disease 2019 (COVID-19) and / or in the Context of Facing Threats that Endanger the National Economy and/or Financial System Stability, Indonesia expands the legal limit of the budget deficit temporarily to 6.3 percent of GDP and launch fiscal stimulus. The fiscal stimulus is planned to be earmarked for supporting government's main concern such as the health sector, social protection and spare business sectors (Kementerian Keuangan RI, 2020). In order to support the top priorities is needed to maintain the supply chains principally for medical items. Other steps taken by government might be seen in Ministry of Finance regulation which gives fiscal incentive and procedural support for ensuring needs aid COVID-19 deterrent and encouraging the acceleration of exports through the concept of medical devices 
monitoring dashboard and fiscal incentive for bonded zone employers and import facilities for export purposes recipient. Since the finite domestic supplies, customs authority becomes vital role to facilitate traffic goods, especially relief goods so it can minimize the impact of the outbreak of novel coronavirus on economies and societies. It is critical for customs authority to provide an integrated and proactive approach with all related board to ensure the integrity and the continuity of facilitation on the global supply chain.

Given the condition above the preliminary steps has been authors' main focus. The procedural supports and fiscal incentives as the main focus of government which are mostly carried out by Customs Authority made authors specified the object of analysis on the roles of customs official. Studies that focus on customs performance as the vital role for overcoming coronavirus pandemic are limited. One of the studies that focus on finding the solution of the pandemic was conducted by Stellinger et al (2020) found that crossborder trading is not the constraint but one of the breakthroughs. Open global markets, where innovative products, services, people and data can flow across countries without unnecessary barriers, contribute to public health and the restoration of our healthy economy.

Bown (2020) found that export restrictions are an expensive form of trade policy. If markets are competitive and market failures are absent, export curbs constrain domestic production and encourage too much local consumption. Taking supplies from global markets could lead to higher world prices and reduced quantities which could hurt needy hospital workers in other countries. Evenett (2020) found that export curbs have no contribution as the solution, they do not enhance increased production or facilitate delivery. Export restraint offers instant sugar highs and a misplaced feeling of control while doing considerable damage at home and abroad. There is no benefit about imposing export restrictions on medical supplies and medicines for the COVID-19 pandemic.

Based on the previous research and explanation above the correlation between policies that has to be implemented by customs authority and its impact to economy are the main interest of the author to conduct a research about customs duties to support supply chain. The objectives of this research are to examine the customs official role on supporting the medical device needs, to analyze the impact of incentives on balance of trade and to discuss how the policy affect the time clearance of medical devices need. 


\section{LITERATURE REVIEW}

\subsection{Customs Role}

Customs authority's role varies and it depends on its country, and usually becomes the subject of standard review and adjustment to guarantee their continuous policies in a continually changing world. Customs has been long mandated and entrusted at borders to play a prominent role with regulating things for which other government services and organizations have policy duty, such as health, agriculture, environment, and trade statistics. This substantial responsibility held by customs authorities reflects the fact of the vital role of customs authority. Traditionally customs authority has been responsible for executing different government approaches, spanning areas as diverse as revenue collection, trade assistance, and social security.

As revenue collector, Customs optimizes the country's revenue. Most of developing countries use import duties and other related taxes as the main focus for their customs authority, for instance in Kenya customs contributes revenue up to $40 \%$ of annual tax collections. The revenue from customs duties helps the countries in funding their activities even though some countries use customs duties as protection of domestic product. Customs duties, called tariffs, provide a competitive advantage in price for local goods compared to similar imported goods for instance in Indonesia. The multifunction of customs duties called tariff is so beneficial for its country.

Trade facilitation according to World Trade Organization (2020) define as "simplification and harmonization of international commerce procedures. Trade methods incorporate the activities, practices and conventions involved in collecting, displaying, communicating and preparing data and other information required for the development of products in international commerce". The role of customs authority as a facilitator is crucial. Cantens and Raballand (2017) said at all fragile borders, customs plays a role as interface-negotiator-peacemaker between traders/haulers and the national or foreign public authorities. Milner, Morrissey, and Zgovu (2008) demonstrated that there is a body of prove to show that progressed trade assistance can (1) Essentially lower trade costs, particularly decreasing time; (2) Bring about significant increases within the volume of imports and exports, that will be even greater than the direct gains from trade policy change; (3) Permit for increases in government revenue and collection productivity; (4) Generally contribute to welfare enhancements and financial growth." 
On the other side, customs authority always takes an important role as border protection (Jones, 2001). Not only increasing the country's revenue but also being deterrent unit to prevent illegal and dangerous goods such as narcotics and counterfeits from other countries. This function also includes countering terrorism threat.

\subsection{COVID-19 Response}

It is necessary to realize that maintaining domestic supply chain is a must (Hobbs, 2020). Since domestic product can't meet national needs for medical supplies, international trade is the only way (Stelingger, A. et al., 2020). There are four main point according to the World Customs Organization's (WCO) highlight of what its members do to mitigate the effect of the COVID-19 pandemic 2nd edition. First, facilitating the cross-border movement of relief and essential supplies. Reducing trade barriers to escalate traffic goods will help the domestic supply problems. Second, supporting the economy and sustaining supply chain continuity (Ireland, 2009; William, 2008). For example, government may support local manufacturer by giving incentive on imported raw materials or by giving tax relief. Third, protecting staff. As the outpost on facing the pandemic, equipping officer on field with adequate protector is as important as the main current objective government to undergo the pandemic and unprotecting staff will make the insufficient staff problem worse. Fourth, Protecting society (Dallimore, 2008; De Wulf, \& Sokol, 2005). The final point is the most global goal focused by every country in the world. Protecting the society is a called for appropriate and integrated movement on responding the pandemic.

World Trade Organization (WTO) released its report on April 3rd, 2020 entitled trade in medical good in the context of tackling COVID-19. In the severe shortage as an impact of the pandemic, the report contains a comprehensive overview of trade and tariffs imposed on relief goods. 
Chart 1. Number of Members per range of average MFN applied tariff (number, percentage)

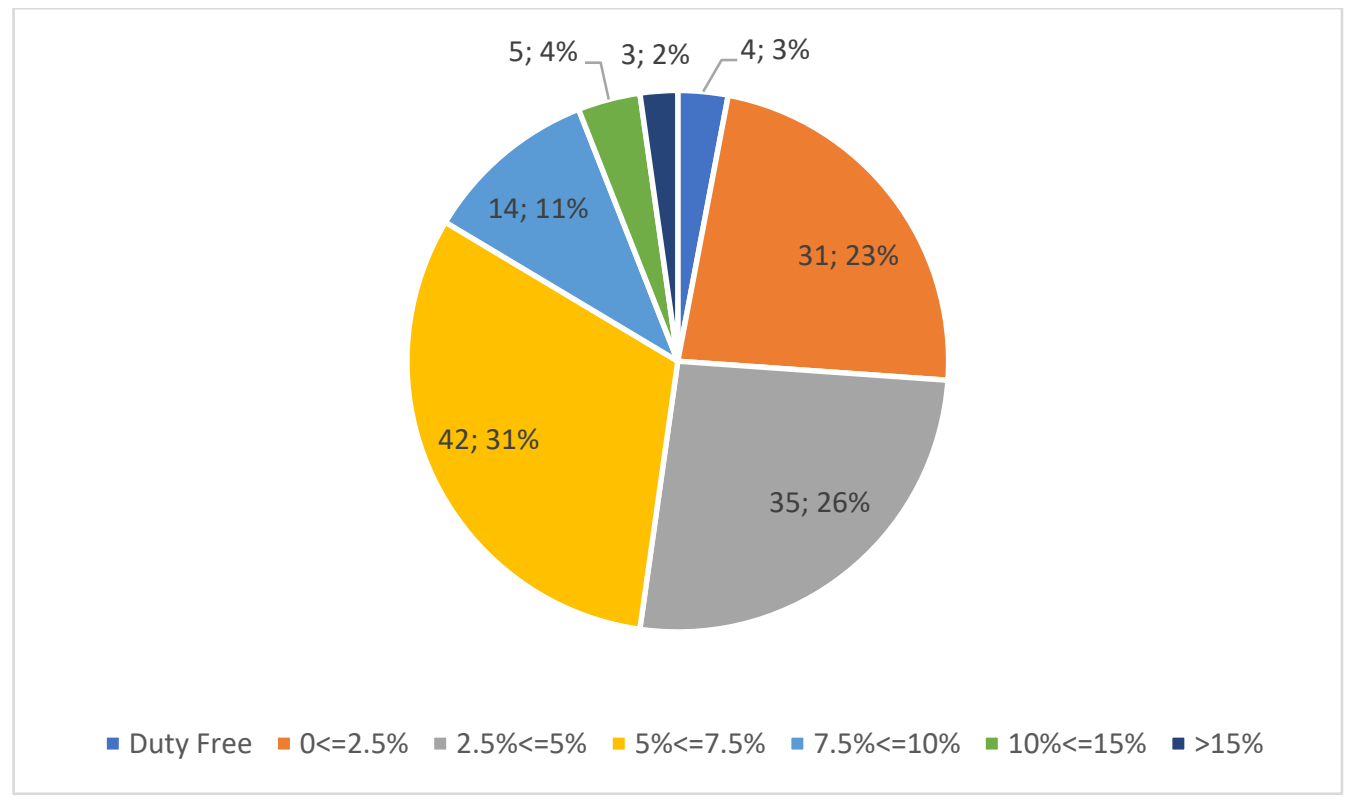

Source: WTO Secretariat, 2020.

There are variations among WTO members applying tariff on COVID-19 preventive product, but more than half of WTO members use applied tariff lower than $5 \%$ (Chart 1) and some do not levy any tariff at all for medical products such as Hong Kong, China; Iceland; Macao, China; and Singapore (WTO, 2020). Twenty three percent of total members applied tariffs from 0 to $2.5 \%$ and twenty six percent of the members have tariffs between $2.5 \%$ and $5 \%$.

Table 1. Number of Members per average MFN applied tariff band;

and average MFN tariff

\begin{tabular}{cccccc}
\hline Duty Range & $\begin{array}{c}\text { All } \\
\text { Products }\end{array}$ & Medicines & $\begin{array}{c}\text { Medical } \\
\text { Supplies }\end{array}$ & $\begin{array}{c}\text { Medical } \\
\text { Equipment }\end{array}$ & $\begin{array}{c}\text { Personal } \\
\text { Protective } \\
\text { Products }\end{array}$ \\
\hline Duty Free & 4 & 72 & 6 & 19 & 5 \\
$0<=2.5$ & 31 & 21 & 20 & 51 & 5 \\
$2.5<=5.0$ & 35 & 18 & 34 & 18 & 19 \\
$5.0<=7.5$ & 42 & 9 & 42 & 28 & 19 \\
$7.5<=10$ & 14 & 11 & 15 & 15 & 9 \\
$10<=15$ & 5 & 3 & 11 & 2 & 30 \\
$>15$ & 3 & 0 & 6 & 1 & 47 \\
\hline Average MFN & $4.80 \%$ & $2.10 \%$ & $6.20 \%$ & $3.40 \%$ & $11.50 \%$ \\
Tariff & & & & &
\end{tabular}

Source: WTO Secretariat, 2020. 
The highest tariff applied on medical product is on the personal protective products with average tariff of $11.5 \%$, it's more than two times higher than all products' average applied tariff. The same holds true for hospital and laboratory inputs and materials with $6.2 \%$ applied tariff on medical supplies. Medicines and medical equipment is lower than average MFN all product tariff. In the midst of unprecedented pandemic, it is essential to co-operate with other countries because COVID-19 is a global scale crisis which continues to exert a substantial toll on economy and society throughout the world so it will be useless just focus on respective countries.

The Organization for Economic Co-operation and Development (2020) is pointing out four important things that can be done in the ongoing global health crisis. First, urge the trade confidence in global market by providing transparency. An integrated, shared information base is critical thing in countering the global pandemic. It also enhances the international cooperation trade and national policy to maintain the supply by keeping trade flowing. Second, keep global supply chains flowing mainly for essential things (Stellinger, 2020). An immediate step to facilitate relief goods such as medical supplies by keeping the trade is essential. Supporting cross-border trade by speeding up physical check, removing tariff and non-tariff barriers and enabling medical researcher by cooperating with them on COVID-19 through transparent data. Third, avoid making things worse. Currently, more than 60 countries have restricted exports of essential goods and increasingly agriculture and food products. Based on the previous crisis in 2007 to 2008 the lesson learned is that export restriction only makes things worse (Bown C. P., 2020). It temporarily raises availability and lower the prices. Furthermore, export restrictions are counterproductive (Evenett S. J., 2020). Denying foreign customers will be ended with the loss of future export sales and will discourage the production of local firms. Last, think beyond the immediate. The policy acted now could have a long term and an important impact globally. Escalating the resilience on supply chain as a part of sustainable development goals by doing more on trade and health to be ready for the next. (OECD, 2020)

\section{RESEARCH METHODS}

Quantitative research is a series of processes of collecting, analyzing, interpreting, and writing the results of a study (Creswell, 2002). The methodology of quantitative research maintains the assumption of an empiricist paradigm (Creswell, 2003). The 
research is independent of the researcher and the data is used to measure reality objectively. Quantitative research creates meaning through the objectivity that is revealed in the data collected.

This study took place in South Tangerang City, Indonesia. Whilst the period of research began in July 2020 until September 2020. According to the objective of this research, the study is quantitative descriptive research. Descriptive research is conducted to give details of the phenomenon and aims to explain the mechanism of the process, present basic information, explain the hierarchy or series and create a set of categories or patterns. Data collected is secondary data and obtained from related institution by request such as Indonesia National Single Window (INSW) and Directorate General Customs and Excise and some taken via online with criteria are extracted from official government website of Indonesia, official online news website, and processed data from relevant sources. The range of information starts from January 2019 to August 2020 according to the availability data.

After obtaining the data and related reference, the information was sorted by its correspondence to the topic namely the customs' role in overcoming the impact of the COVID-19 pandemic, then processing the data according to the topic. Data analysis conducted in the form of graphs with a descriptive narrative related to the objectives of the research.

\section{ANALYSIS AND DISCUSSION}

\subsection{Customs' Role on Supporting Medical Needs}

The key role to undergo COVID-19 pandemic is adequate supply in crucial products (Hobbs, 2020). In the beginning year of 2020 since confirmation of the first case of COVID-19 in Indonesia, the promptitude and feasibility of healthcare system had been on the public spotlight and the severe of shortage medical supply cases across provinces makes the condition even worse mainly because the lack of personal protective products such as masks and hand sanitizer. 
Chart 2. Medical Device Monitoring Dashboard (in thousands)

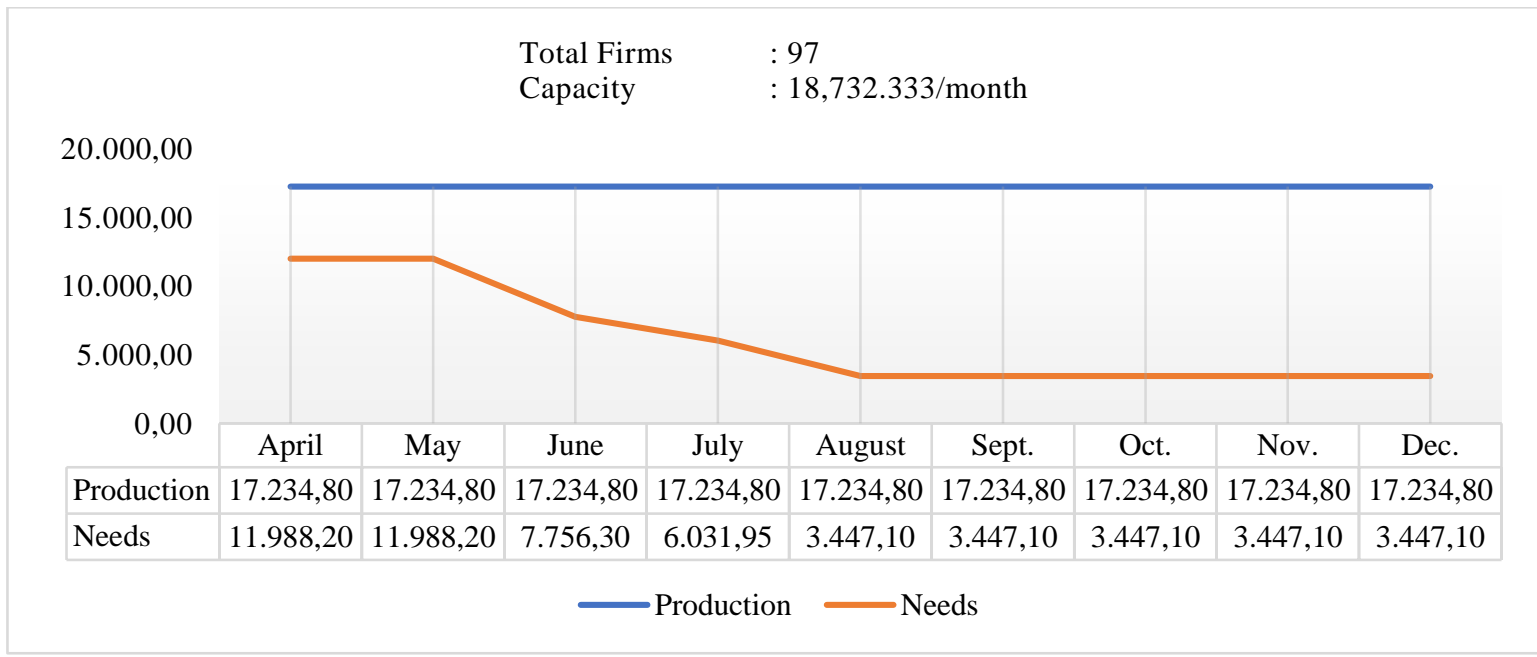

Source: Kemenperin (production \& needs), update 27 Mei 2020 14:00.

However, the medical device monitoring dashboard developed by related parties and government showed the opposite condition (Chart 2). Discrepancy between the data with the field condition was caused by the consumer behavior (Arafat et. al, 2020). Perception of medical support product scarcity felt by public and it does not just take place in Indonesia. In Hungaria, panic buying happened in March 2020, the major respondent (87\% of people involved) in research conducted by Andras and Tamas (2020) reported there was a significant increase in their expenditure. The COVID-19 pandemic had a major impact on the entire retail sector in Hungary as a result of changes in customer spending behavior. The condition is quite similar to what happened in Indonesia, the limitation of personal protective products in Indonesia can be seen in curtailment to wear personal protective equipment such as masker in February. Increasing in prices and scarcity of masks make government prioritize medical personnel to wear a mask than public. This situation depicts that the resilience of domestic supply chain can't respond to the changing spending behavior so to meet the needs of medical supply, government has to provide the medical products from other countries.

Answering customer spending behavior res, the government takes preliminary action through customs authority. Ministry of Finance via PMK-34/PMK.04/2020 facilitates imported goods for handling COVID-19 purposes by giving fiscal incentive in taxation and import duty and as seen in Chart 3, there is escalating in medical device import documents. 
Chart 3. Number of Medical Device Import Documents

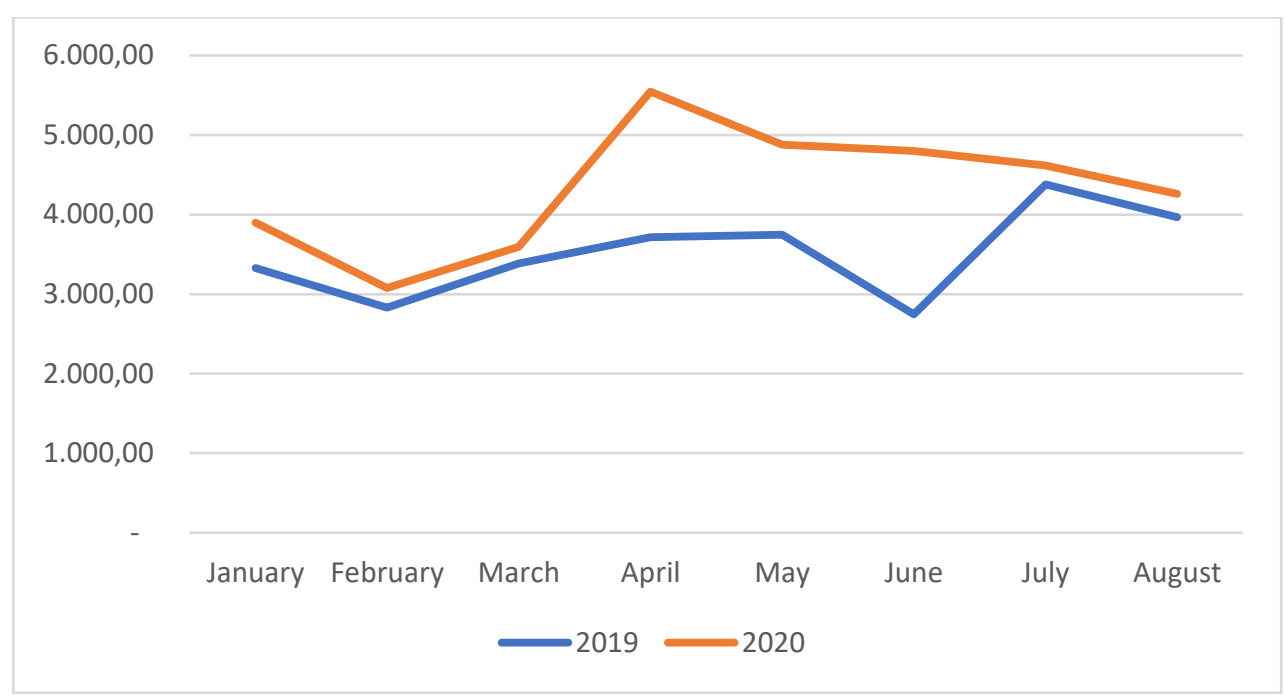

Source: Direktorat Jenderal Bea dan Cukai, 2020.

The escalation of medical device importation proves that the fiscal incentives are effective on trade performance (Helble et al., 2009; Cali and te Velde, 2011). Increasing in medical device imported goods contributes to medical product inputs in hospitals and distribution of personal protective equipment spreading evenly in public. As seen in Chart 3, the highest number of medical devices import documents occurred in April as response of World Health Organization's appeal to everyone to wear a mask, especially when doing activities outside. In the following months, declining on import document occurred as a prove of availability of several types of medical goods specifically hand sanitizer, products that contain disinfectants, masks, and certain types of protective clothing so PMK-34/PMK.04/2020 was perfected by PMK-83/PMK.04/2020 enhancing national economic growth in industrial sector of hand sanitizer, products that contain disinfectants, masks, and certain types of protective clothing. It changes the total number of medical imported goods facilitated from 73 items to 49 items.

In addition, there is procedural support besides fiscal incentives. The procedural support described in PMK-45/PMK.04/2020 relieves in submitting certificate of origin and invoice declaration by email. Furthermore, Keppres Nomor 9 Tahun 2020 provides exemption from the import trade system to National Disaster Management Authority in order to accelerate handling on COVID-19. The steps taken by government have been in line with OECD (2020) recommendations for providing integrated information through related institutions which is realized with Medical Device Monitoring Dashboard and as 
for supporting trade flowing, government facilitates by fiscal and procedural relief. In maintaining supply chain and assisting domestic industries, customs takes vital position on implementing and executing the regulations. Customs authority support domestic industries by giving simplicity in procedure and related-tax relief so they avoided bankruptcy, furthermore license processing is available via single submission online as integrated and coordinated related agencies. In the public interest, customs encourage feasibility and availability of medical needs accelerating trade flow (WCO, 2020).

\subsection{The Impact of Fiscal Incentives}

During the pandemic, governments have intervened on an enormous scale to keep businesses alive. A combination of incentive assistance schemes, tax relaxation, loosening of provisions, and laws or other measures to stop bankruptcies has prevented a wave of company failures. This fiscal incentive aid was a necessary feature of this year's economic rescues. According to Hannan et al. (2020) Fiscal policy is essential so that a country can cope with the pandemic, recover the economy quickly and rebuild its fiscal buffer in the medium term. Fiscal resources are needed in the near future to accommodate additional spending on health care and emergency services and to protect worthy people and enterprises through a timely, targeted and temporary life path. In Indonesia, there are fiscal incentives for facility users of ease of import for export purposes (KITE) and bonded zone $(\mathrm{KB})$. The facilities provided in order to escalate economy growth by increasing export value. The ratio between export value and import value of the facility recipient used in measuring success rates government on enhancing economy.

Based on an internal survey conducted by the Directorate General of Customs and Excise on stakeholders of KITE and KB facilities users, it is found that there are constraints on the export of production products due to many export destination countries locking down. As a result of the lockdown policy, it effects on companies using KITE facilities such as a decrease in the value of imports, exports and obstacles in the production process. Another impact is that business processes stop and there are companies that stop or close their companies. The process of shipping goods is also hampered due to an increase in shipping costs. Companies that use KITE facilities also encounter problems in the process of importing raw materials. This is indicated by the chain effect of lockdowns carried out by countries sending raw materials. 
Companies that have $\mathrm{KB}$ facilities also have problems that are almost similar to KITE companies. Constraints on the export of products due to the lockdown of export destination countries. These constraints have an impact on companies such as difficulty in raw materials and disruption of the production process, a decrease in import and export values, a reduction in labor and a reduction in production in certain lines. KB companies also have problems importing raw materials. Addressing the constraint, the Government of the Republic of Indonesia through the Minister of Finance Regulation Number PMK 31/PMK.04/2020 concerning Additional Incentives for Companies Receiving Bonded Zone and/or KITE Facilities. This incentive is given to companies that receive bonded zone facilities $(\mathrm{KB})$ and companies that receive facilities for import facilities for export purposes (KITE).

There are facilities for Bonded Zone (KB) Facility Recipient Companies. Firstly, relaxation of selling products to local. The sale of KB companies' products to the local is allowed without reducing the sales quota for the current year. Selective physical inspection utilizes information technology and if the area is designated as a large-scale social distancing area, the Bonded Piling Place (TPB) can be granted an independent service approval. The import of masks, PPE and others is subject to suspension of Import Duty and Import Tax as long as it is used in Bonded Zone.

There is no significant difference between KITE facilities and KB facilities. The following are facilities for companies receiving Export Destination Import Facility (KITE). Import of goods from local in order to be processed for export purposes is not subject to value-added tax (PPN) or sales tax on luxury goods (PPnBM). Submission of products to be processed/combined with KB/KITE IKM products is allowed. Sales of products to the local are allowed for the KITE exemption and the KITE IKM at a maximum of $50 \%$ of the export value of the previous year. The KITE exemption and the KITE IKM are allowed to submit production products for handling the COVID-19 disaster to the government or people who obtain domestic import duty and import tax exemptions without reducing the quota.

Another incentive provided by the Government of the Republic of Indonesia through the Directorate General of Customs and Excise is the Ethyl Alcohol Excise Exemption in accordance with SE-04/BC/2020. Factory entrepreneurs can apply for ethyl alcohol excise exemption for social purposes in the context of preventing and overcoming 
COVID-19. The facilities provided consist of Exemption from excise on ethyl alcohol for social purposes in the context of preventing and overcoming Covid-19. Acceleration of services and technical guidance related to the provision of excise duty on ethyl alcohol as raw material or supporting material for the manufacture of hand sanitizers, surface sanitizers, antiseptics, and the like as a follow-up to prevent the spread of Covid-19.

The incentives above given in order to prevent as much as possible the declining of export value because of COVID-19 pandemic. Based on fiscal incentives above, authors try to analyze the impact of fiscal incentive by providing KITE/KB Ratio and compare it to the previous ratio in 2019. The ratio generally uses to show the effectiveness of the facilities to the economy but in this research the ratio will be used to see the impact of additional incentives to the facility users on sustaining economy through export value.

Chart 4. KITE/KB Export to Import Ratio

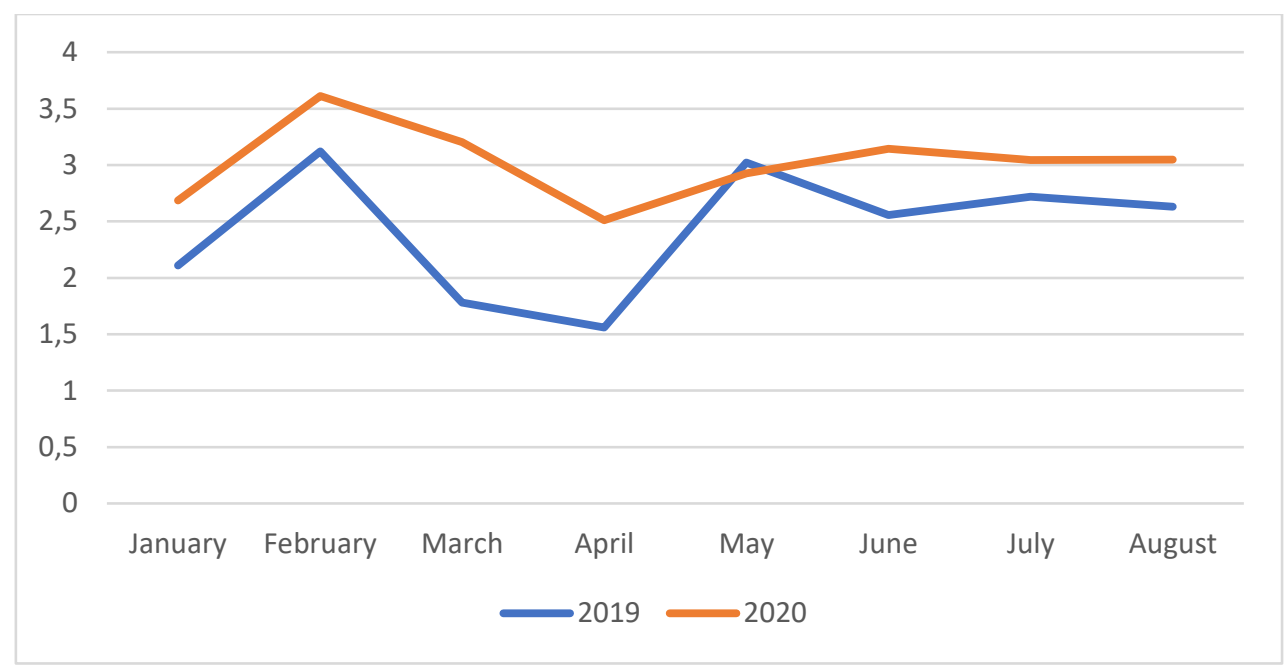

Source: Direktorat Jenderal Bea dan Cukai

Based on chart 4 there is a positive result (as seen in Chart 4) for providing additional incentives to the facility user. It is found that there is slight rise in KITE/KB ratio of 2020 than the ratio in 2019, the government has made right decision on sustaining economy through fiscal incentives. Escalation in KITE/KB ratio will contribute directly to national balance trade. The result is almost similar to those reported by Ashenafi and Getaneh (2013) found that the incentive is positively correlated with export value so there are improvements in the export sector in term of export value, destination and diversification. In the work (Casado, M. G. et al., 2020) proves that the fiscal stimulus issued in response to economic shocks caused by COVID 19 has an important and substantial effect on 
economic spending and activity. Furthermore, the incentives encourage domestic firms to take a part on maintaining global supply as mentioned by OECD as four important things can be done in the ongoing pandemic (Becker, Egger, \& Merlo, 2012).

\subsection{Accelerating the Flow of Goods}

Based on ease of doing business index by World Bank (accessed on Sept $1^{\text {st }} 2020$ ), Indonesia is ranked 116 of 188 on trading across borders categories. The index shows us that Indonesia is lagging far behind on trading across borders system comparing to other countries. Most of countries rely on cross-border trade on prioritizing their emergency needs in medical equipment, and Indonesia as well. Indonesia has made solemn attempt to prompt the flow of goods by reducing trade barriers. In general, the barrier of international trade is classified into tariff and non-tariff barrier. As discussed at 4.2 about fiscal incentives in reducing the tariff barrier, at this point will be focused on non-tariff barrier.

Industrial policies aimed at strengthening the health sector and reducing reliance on global supply chains could accelerate the trend of automation involving goods essential to national security (The Hill 2020) WEF Article. Giving procedural supports in international trade, customs authority provides easiness in reporting certificate of origin mentioned in SE-07/BC/2020 (applied on March 30, 2020) as a follow-up from PMK45/PMK.04/2020 and adheres central government focus on accelerating the flow of COVID-19 countermeasure goods by making an integrated move with decree with the National Disaster Management Agency, Director General of Customs and Excise Number 01/BNPB/2020, KEP-113/BC/2020 (applied on March 20, 2020). The regulations hoped can reduce non-tariff barrier trig domestic medical needs by classified the COVID-19 countermeasure goods as specific goods which retrieve rush handling facility. Furthermore, National Single Windows Institution provide single submission online via Indonesia National Single Windows (INSW). The platform helps stakeholder to process their license to any related agencies at once. INSW is integrated and coordinated cooperation of government institution to encourage the flow of goods.

In order to see the impact of steps taken by government, authors tried to provide processed dwelling time data from Soekarno Hatta Customs Office. The data depicts facilitated goods based on PMK-34/PMK.04/2020. In Table 2 we focus on data once the rules are applied namely in April to June. Data of 2019 as comparative data highlighted 
by gray color and the orange indicates that there is an increase on dwelling time compared to data from 2019 and the green indicates there is a reduction on dwelling time compared to 2019 .

Table 2. Average Dwelling Time per Document Comparison of Medical

Supplies in hour

\begin{tabular}{|c|c|c|c|c|c|c|c|c|c|c|c|c|}
\hline \multirow[t]{2}{*}{ Per } & \multicolumn{2}{|c|}{$\begin{array}{l}\text { Personal } \\
\text { Protective } \\
\text { Equipment }\end{array}$} & \multicolumn{2}{|c|}{$\begin{array}{c}\text { Hand } \\
\text { Sanitizer \& } \\
\text { Products } \\
\text { Containing } \\
\text { Disinfectants }\end{array}$} & \multicolumn{2}{|c|}{ Medicine } & \multicolumn{2}{|c|}{$\begin{array}{l}\text { Medical } \\
\text { Equipment }\end{array}$} & \multicolumn{2}{|c|}{$\begin{array}{l}\text { Test Kit And } \\
\text { Laboratory } \\
\text { Reagents }\end{array}$} & \multicolumn{2}{|c|}{$\begin{array}{l}\text { Virus } \\
\text { Transfer } \\
\text { Media }\end{array}$} \\
\hline & '19 & '20 & 19 & '20 & '19 & '20 & '19 & '20 & '19 & '20 & '19 & '20 \\
\hline Jan & 86 & 203 & 156 & 167 & 162 & 170 & 155 & 150 & 145 & 117 & 119 & 98 \\
\hline Feb & 99 & 104 & 106 & 210 & 153 & 150 & 155 & 117 & 121 & 102 & 135 & 80 \\
\hline Mar & 135 & 94 & 222 & 96 & 172 & 138 & 165 & 126 & 138 & 100 & 146 & 87 \\
\hline Apr & 137 & 165 & 127 & 223 & 161 & 174 & 174 & 168 & 136 & 113 & 156 & 122 \\
\hline May & 131 & 213 & 189 & 161 & 173 & 188 & 140 & 164 & 145 & 124 & 110 & 112 \\
\hline Jun & 196 & 248 & 169 & 342 & 131 & 139 & 139 & 149 & 108 & 121 & 118 & 115 \\
\hline
\end{tabular}

Source: KPU BC Soekarno Hatta

As shown in table 2 two-thirds of the data show an increase in dwelling time and less than half show dwelling time efficiency. Pre-clearance component dominates dwelling time proportion than customs clearance. Post clearance has already reduced to zero since automation of gate out applied. The results are not in accordance with the research conducted by Jarmon (2009) who states that customs procedures can impact dwelling time which may cause delays or accelerate the flow of goods. Dwelling time is a comprehensive matter involving various factors in the whole process. Government through Customs Authority and National Disaster Management Agency Based have provided procedural supports and in collaboration with National Single Window Institute provide online single submission.

Based on previous research, dwelling time is affected by regulators, post operators and stakeholders (Sherly, 2017) concluding that the nescience of stakeholder about process flow and facility provided also affect the pre-clearance time. Furthermore, Moini et al (2012) explained that terminal location and function, port management and policies, shipping and trucking company performance and management, type of container, type of goods, container security level, shipper performance, goods owner performance and forwarder performance can impact dwelling time as well.

Government countermeasures are already in line with the highlight of WCO (2020) in reducing trade barrier and sustaining supply chain continuity. According to the 
OECD (2020) suggestion, Indonesia provides integrated shared information, keeps global supply chain flowing by encouraging acceleration in medical items export by the concept of medical devices monitoring dashboard. One thing to watch out by the government in sustaining supply chain is there are other factors affecting dwelling time which can be taken into consideration in reducing dwelling time.

\section{CONCLUSION}

The COVID-19 outbreak has become the most incommoding global crisis and its domino effect to numerous sectors makes it more difficult to overcome. The most constraint suffered by all countries is the severe shortage of medical items. Increasing in demand of medical items mainly personal protective equipment because of COVID-19 makes medical personnel lack of their supplies. In addition, the pandemic also hits hard global economy. Various policies and measures to undergo the pandemic made also have negative impact to global economy. In Indonesia, the policies such as large-scale social distancing, school closures, and work from home also affect its economy. In order to overcome COVID-19 pandemic Indonesia has made preliminary steps. One thing highlighted is supply chain, sustaining the supply chain continuity is vital to satisfy the public needs of medical items.

In order to maintain domestic supply chain, government play the vital role through customs authority. Customs has been trusted in facilitating and controlling of goods flow. In Indonesia, customs authority serves as trade facilitator, community protector and revenue collector. In overcoming coronavirus, customs cooperates with associated institutions provide numerous tools such as single submission online, simplicity in procedure and related-tax relief so domestic firm might avoid bankruptcy. Medical Device Monitoring Dashboard (MDMD) has been built for monitoring domestic's robustness on producing medical device, MDMD can be a tool to support trade flowing and encourage export once domestic supply satisfied.

The fiscal incentives and procedural supports are policies expected to increase the availability of medical items via international trade. Customs, government institution responsible for international trade, are mandated to implement and execute the policies. Fiscal incentives mainly for facility users of ease of import for export purposes (KITE) and bonded zone $(\mathrm{KB})$ are proved preserve the economy by supporting export value. The $\mathrm{KITE} / \mathrm{KB}$ ratio used to measure success rates of the facility is used to see the impact of 
additional incentive for the facility users to economy. Providing additional incentives to the facility user shows an escalation in KITE/KB export to import ratio which will be impact on national balance trade.

Moreover, procedural supports such as single submission online, relaxation of certificate of origin submission, and rush handling provided to accelerate the COVID-19 countermeasure goods flow are not enough to decrease dwelling time on its clearance. It happens because dwelling time is a comprehensive process involving many parties and not only the government. We recommend to give a holistic approach to reduce dwelling time on cross-border trade. One approach that can be taken by the Government or Customs Authority is to create an Online Integration Monitoring Goods Movement between relevant agencies in this case DJBC, BNPB and Courier Service Companies. On this Monitoring Dashboard, it is hoped that it can monitor the movement of special COVID items starting from getting off the plane (pre-clearance) to Customs Processing (Customs Clearance). The government needs to issue strict regulations regarding the standard time for releasing COVID 19 rush handling items. Joint Kep 113 BC 2020 only explains the procedure for releasing goods without mentioning the standard time or service promise required. We suggest that there are further regulation providing standard operating procedure in detail including time limitation of giving permittion.

\section{LIMITATIONS AND SUGGESTIONS.}

This study is conducted in ongoing COVID-19 pandemic, it might show different result if the study was conducted after the COVID-19 pandemic ended. The data period used in this study starts from January 2020 to August 2020 depending on the availability of the data with using data of January 2019 to August 2019 as comparative data and the policies taken by central government has significant influence on customs authority in Indonesia so it might be different in the results if the data took longer period and there were change in policies. In addition, the dwelling data used in analyzing the acceleration of COVID-19 countermeasures goods taken from Soekarno Hatta Customs Office, in the next research it is suggested to use dwelling time data from all of the terminal in Indonesia. Medical Devices Monitoring Dashboard provided by the government uses estimated production and demand data from related institutions so it does not reflect the real data of production and needs. The result might be more relevant if the production and demand data use the real time data. It is necessary to take as consider of analyzing non- 
tariff barrier besides government policy to conduct better result in accelerating the goods flow analysis.

\section{ACKNOWLEDGEMENT}

The authors wish to thank Mr. Fauzan (National Single Window Institution) for his contribution. We also thank Mrs. Dina and Mr. Sidik (Directorate of Customs and Excise Information) for providing data. We Thank Mr Hanif from KPU Soetta. We thank Mr. Amrie Firmansyah and Mr. Akhmad Solikin (Polytechnic of State Finance STAN) for providing us research permit. We thank Mr. Ario Seno Nugroho and Mrs. Indri Riesfandiari (Polytechnic of State Finance STAN) for giving us advice.

\section{REFERENCES}

András, K., \& Tamás, S. T. (2020). Panic buying in Hungary during COVID-19 disease. https://doi.org/10.13140/RG.2.2.21264.76800

Anita, S. L., \& Asmadewa, I. (2017). Analisis Dwelling Time Impor Pada Pelabuhan Tanjung Priok Melalui Penerapan Theory Of Constraints. Jurnal Perspektif Bea dan Cukai, 1, 73-87.

Arafat, S. M. Y., Kar, S. K., Marthoenis, M., Sharma, P., Apu, E. H., Kabir, R., ... Kabir, R. (2020). Psychological underpinning of panic buying during pandemic (COVID 19). Psychiatry Research. https://doi.org/10.1016/j.psychres.2020.113061

Becker, S., Egger, P., \& Merlo, V. (2012). How low business tax rates attract MNE activity : Municipality - level evidence from Germany. Journal of Public Economics, 96(9-10), 698-711.

Bown, C. P. (2020). COVID 19 : Demand spikes, export restrictions and quality concerns imperil poor country access to medical supplies. COVID-19 and Trade Policy :Why Turning Inward Won't Work, 31-47.

Dallimore, C. (2008). Securing the supply chain: does the container security initiative comply with WTO law. (PHD Thesis Wilhelminian Universiy of Munster, 2008).

Cali, M., \& Velde, D. W. T. (2020). Does Aid for Trade Facilitation. World Development, 35,5 725-40.

Cantens, T., \& Raballand, G. (2017). Cross-Border Trade, Insecurity and the Role of Customs : Some Lessons from Six Field Studies in (Post-)Conflict Regions. International Centre for Tax and Development Working Paper, 67, 1-23.

Casado, M. G., Glennon, B., Lane, J., McQuown, D., Rich, D., \& Weinberg, B. A. (2020). The Effect of Fiscal Stimulus Evidence From COVID-19. NBER Working Paper, 27576, 12.

Creswell, J. (2002). Educational research : Planning, conducting, and evaluating quantitative and qualitative research., ( $2^{\text {nd }}$ Ed.). Upper Saddle River, NJ: Merrill Prentice Hall.

Creswell, J. (2003). Research Design : Qualitative, quantitative and mixed methods approaches he unabridged journals., ( $2^{\text {nd }}$ Ed.). Thousand Oaks, CA: SAGE Publications. 
Evenett, S. J. (2020). COVID 19 : Export curbs on medical goods won't tackles shortages. COVID-19 and Trade Policy: Why Turning Inward Won't Work, 49-61.

Fachriansyah, R., Gunawan, A., \& Hasani, A. (2020, March 22). COVID-19: Inadequate medical supplies take toll on lives of Indonesian medical workers. The Jakarta Post. Retrieved from https://www.thejakartapost.com/news/2020/03/22/covid-19inadequate-medical-supplies-take-toll-on-lives-of-indonesian-medical-workers.html

Hannan, S. A., Honjo, K., \& Raissi, M. (2020). Mexico Needs A Fiscal Twist : Response to COVID-19 and Beyond. IMF Working Paper, WP/20/215. 31.

Helble, M., Mann, C., \& Wilson, J. (2020). Aid for Trade Facilitation. Policy Research Working Paper No. 5064, Washington, DC : The World Bank.

Hobbs, J. E. (2020). Food supply chains during the COVID-19 pandemic. Canadian Journal of Agricultural Economics, Vol 68.

International Trade Center (2020). Market Access Map. Retrieved from https://macmap.org/en/covid19

Ireland, R. (2009). The WCO SAFE Framework of Standards : avoiding excess in global chain security policy. WCO Research Paper,No. 3, Brussels:World Customs Organization.

Jarmon, J. (2009). A Rationale for the "Trusted Shipper" - How Programs Such As CTPAT and SAFE May Be The Elements Of A New Defense Paradigm (Doctoral dissertation, The State University of New Jersey, 2009). UMI Dissertation Publishing, 1-162

Jones-Correa, M. (2001). Border games : policing the US-Mexico divide. Journal of Policy Analysis and Management, vol. 21. No. 1, pp. 1-162

Kementerian Keuangan Republik Indonesia. (2020). Menjaga Ekonomi Indonesia Terhadap Dampak Negatif Pandemik COVID-19. Jakarta: Biro Komunikasi dan Layanan Informasi.

Milner, C., Morrissey, O., \& Zgovu, E. (2008). Trade Facilitation in Developing Countries. CREDIT Research Paper,08/05, 1-34.

Organization for Economic Co-operation and Development. (2020). COVID-19 and International Trade: Issues and Actions. Paris: Author.

Organization for Economic Co-operation and Development. (2020). Making Trade Work for All. Paris: Author.

Organization for Economic Co-operation and Development. (2020). OECD Interim Economic Assessment Coronavirus: Living with Uncertainty. Paris: Author.

Seric, A., \& Winkler, D. (11 May 2020). COVID-19 could spur automation and reverse globalization - to some extent. In World Economic Forum. Retrieved from https://www.weforum.org/agenda/2020/05/covid-19-automation-globalisationcoronavirus-world-pandemic-change/?

Stellinger, A., Berglund, I., \& Isakson, H. (2020). How trade can fight the pandemic and contribute to global health. COVID-19 and Trade Policy: Why Turning Inward Won't Work, 21-30.

William, J. (2008). Bernstein A Splendid Exchange : How Trade Shaped the World. Atlantic Monthly Press, 1, 467 p.

World Customs Organization. (2020). What Customs Can Do to Mitigate The Effects of The COVID-19 Pandemic. Brussels: Author.

World Trade Organization. (2020). Trade in Medical Goods in The Context of Tackling COVID-19. Geneva: Author. 